\title{
Decarbonising tourism: Mission Impossible?
}

Prof Susanne Becken, Director of Griffith Institute for Tourism, Griffith University, Queensland, Australia; and School of Hospitality Management and Tourism, University of Surrey, United Kingdom.

Email: s.becken@griffith.edu.au

Please cite as: Susanne Becken (2019) Decarbonising tourism: mission impossible?, Tourism

Recreation Research, DOI: 10.1080/02508281.2019.1598042

Acknowledgement: I would like to thank Prof Ken Hughey and Dr Emma Whittlesea for their critical and very helpful comments. My sincere thanks also to Rochelle Turner and Geoffrey Lipman for providing feedback. I am also very grateful to Prof Bernard Lane who gave me his wisdom both as a longstanding expert in sustainable tourism and as an editor; his input has improved the manuscript substantially. All the arguments made are mine and may not reflect the views of those colleagues who read the manuscript.

\begin{abstract}
The tourism industry collectively seeks to portray itself as being proactive in embracing climate action, but is the sector doing enough to decarbonise to the extent agreed on in the Paris Agreement? This paper presents a constructive critique of the key mechanisms that presently define the global travel and tourism industry's attempts to reduce greenhouse gas emissions. Six key challenges are identified and each constitutes a major hurdle to rapid and substantial progress. These are: tourism's embeddedness in the prevailing growth paradigm, the institutionalisation of interests, the nature of policy making, the inadequacy of incremental improvements, the focus on technological efficiency instead of (behavioural) conservation, and the global distribution of tourism. The paper concludes by suggesting that only systemic changes at a large scale will be sufficient to break or disrupt existing arrangements and routines. Tourism academics should contribute to identifying and helping to implement solutions, but this will require much greater collaboration with the industry and government, as well as with researchers from a broad range of disciplines.
\end{abstract}

Keywords: Decarbonisation, carbon footprint, neoliberalism, tourism system, governance, destinations 


\section{Introduction}

The tourism industry collectively seeks to portray itself as being proactive in embracing the decarbonisation narrative. In 2018, the World Travel and Tourism Council (WTTC, 2018a) announced a 'common agenda' with the United Nations Framework Convention on Climate Change (UNFCCC). The agenda highlights the need to reduce the contribution of the travel and tourism industry to climate change and to support quantitative reductions targets. A little earlier, the International Tourism Partnership (ITP, 2017) had released the Hotel Global Decarbonisation Report, which provides a science-based target approach for the hotel industry to reduce emissions. The report shows that an average hotel would need to cut emissions by $66 \%$ by 2030 and by $90 \%$ by 2050 , compared with 2010 emissions. Such reductions are necessary to deliver a fair contribution to the goals specified in the 2016 Paris Agreement (UNFCCC, 2017).

The Paris Agreement is the current global framework that addresses climate change. It was adopted by 195 nations at the 21st Conference of the Parties to the UNFCCC in December 2015 and the Paris Roadmap is now being developed to accelerate action (Scott, Hall, \& Gössling, 2016). Tourism activity, and related emissions, fall under the jurisdiction of states and their so-called National Determined Contributions (NDC), or in other words country-specific reduction targets. It is likely that there will be increasing pressure on tourism businesses to measure, monitor and reduce greenhouse gas (GHG) emissions (Becken \& Bobes, 2016).

Global tourism contributes about $8 \%$ of anthropogenic emissions, whereby about half of the $4.1 \mathrm{Gt}$ of carbon dioxide equivalent (CO2-e) emitted in 2013 were due to transport (for a detailed breakdown, see Lenzen et al., 2018). Other major sources of emissions relate to the electricity used by hotels and restaurants, and the production of material goods consumed by tourists. Aviation emissions cause particular concern because of the rapid growth in the sector and the lack of imminent solutions for decarbonisation. Domestic aviation, which makes up about $38 \%$ of all aviation emissions (Becken \& Mackey, 2017), are covered within NDCs, but the remaining $62 \%$ of emissions from international aviation have to be dealt with separately. The International Civil Aviation Organisation (ICAO) has developed a 'basket of measures' that includes operational and technological efficiency gains, alongside a market-based approach that seeks to deliver "Carbon-Neutral Growth 2020" (ICAO, 2016). The Carbon Offset and Reduction Scheme for International Aviation (CORSIA) is the primary mechanism to achieve this (Lee, 2018).

The recently released 1.5 degree Celsius $\left({ }^{\circ} \mathrm{C}\right)$ report by the Intergovernmental Panel on Climate Change (IPCC, 2018) leaves no doubt that absolute and rapid reductions in GHG emissions are critical. It presents substantial evidence on the seriousness of expected climate change impacts, for example, coral reefs are likely to decline by a further $70-90 \%$ under a $1.5^{\circ} \mathrm{C}$ warming, or over $99 \%$ at $2^{\circ} \mathrm{C}$. Limiting global warming to $1.5^{\circ} \mathrm{C}$ demands "rapid and far-reaching transitions in energy, land, urban and infrastructure (including transport and buildings), and industrial systems" of an "unprecedented" scale (IPCC, 2018, p. 17). The only way to achieve this is by deep emission cuts across all sectors, including tourism. To meet the $1.5^{\circ} \mathrm{C}$ target, emissions would have to decrease by $45 \%$ between 2010 and 2030 and reach 'net zero' by 2050 .

The Club of Rome (2018) calls for a Climate Change Emergency Plan to address the "existential risk to humanity" (p. 5), identifying inaction and lack of moral responsibility as root causes of systemic collapses on multiple fronts. Are tourism agencies and businesses part of this inaction, and are they doing enough to achieve rapid emission reductions? Or are 'we' pretending that we care (or embracing it in principle but not in practice) whilst continuing business-as-usual? By impressing that sector-wide climate action is being taken to reduce emissions, when it may only be a minority, will deliver at best incremental improvements, and at worst hinder a more substantial transition.

The role of academics is to consider, critique and communicate; in other words to "provide enlightened leadership" (The Club of Rome, 2018, p. 6). Following a year of catastrophic impacts from numerous extreme climate events in 2018 , it is timely to critically reflect on climate change action in the tourism sector. This paper represents a scholarly perspective piece that investigates the prevailing paradigm and institutions and seeks to uncover stumbling blocks towards substantial 
progress in emissions reductions. In doing so, six principal challenges of why the tourism sector's carbon footprint has been growing and why future decarbonisation is proving difficult to achieve have been identified. The arguments made draws on the knowledge and experience by the author, relevant literature (including pertinent cases which facilitate inductive reasoning) and theories that help understand underlying mechanisms. As a result, this paper presents an original and extensive assessment of one of the key issues related to tourism; its carbon footprint. This paper presents systemic and principal challenges, and it is acknowledged that micro analyses of particular types of tourism or destinations might yield additional or contrary insights. Also, the delineation of tourism is a fluid one and does not follow statistical definitions, but rather focuses on the 'phenomenon' of tourism, hence players and perspectives that go beyond what one might call the 'tourism sector'. Suggestions for ways forward are presented in the conclusion.

\section{The Growth Paradigm}

Despite some evidence of success in terms of GHG reductions, the tourism sector faces a major challenge, namely the seemingly insatiable demand for travel, and the industry's desire serve or stimulate that demand. The global statistics provided by the United Nations World Tourism Organisation (UNWTO) highlight that tourism is not only a growing industry, but also one that grows faster than the rest of the world economy. In 2017, international arrivals grew by $6.8 \%$ (UNWTO, 2018a). Tourism growth is particularly problematic when it involves long-haul travel or other forms of high-carbon transport.

\section{"Growth is good"}

"Capitalism has fundamentally changed our relationships with one another and with the Earth" (Mann \& Wainwright, 2018, p. 99). It is at the core of the conversion of the 'planet' into sellable goods, and necessitates continues growth to generate return on economic capital. Capitalism as a social formation has now spread widely beyond the Western world (reaching China in the form of state capitalism), making it more difficult to reduce humanity's impact on the climate (ibid, 2019). Tourism is firmly embedded in the growth paradigm where planning and policy are built on beliefs in infinite growth, technological progress, and liberal democracies (Becken, 2016; Kilbourne, Beckmann \& Thelen, 2002). Techno-optimism is particularly evident in discussions on tourism's resource use (Becken \& Dolnicar, 2016; Warren \& Becken, 2017). Technological advances are seen to be enabled by minimal government intervention, free markets and extensive private property rights (Kilbourne et al., 2002). The expansion of tourism's new digital economy is evidence of the sector's belief in technology to deliver growth. Digital systems have the potential to deliver 'smart' solutions and maximise efficiency, but more often than not they are deployed to enhance tourism consumption ${ }^{1}$.

Advances in transportation and new business models (e.g. low-cost airlines), in combination with increasing disposable incomes, have facilitated exponential growth both from established and emerging economies. Climate change concerns are becoming part of the public discourse (Dwyer, 2018), but individual and collective action remain marginal and are often balanced against personal or economic benefits from tourism (Higham et al., 2014; UN Climate Change, 2018). The media play an important role here, as they amplify the discourse using descriptive language such as 'removing barriers', 'red tape' and 'boost marketing' (ABC, 2016). The neoliberal agenda is challenged by only a few (e.g. Dwyer, 2018; Pollock, 2015; Simmons, 2017), who recognise tourism growth as a risk to the environmental, the visitor experience and social well-being. Continuation of tourism growth in its current form is incompatible with global climate goals (Gössling et al., 2010).

\footnotetext{
${ }^{1}$ Increasing tourism's dependence on digital technologies bears some risks, especially when a small number of very large companies accumulate considerable power. At the same time, this disruption has the potential to undermine existing systems and players (see below), especially when decentralised systems challenge existing ways of 'doing business'.
} 


\section{From growth to well-being}

Shifting to a new paradigm that does not have economic growth at its core is not easy, but momentum is building towards a broader view of what is desirable and how to measure positive outcomes for societies (Pollock, 2015). The OECD (2017) has presented a range of frameworks and indicators for measuring well-being as part of its 'How's life?' work. Building on approaches such as the 'Genuine Progress Index' and 'Gross Happiness Product', an increasing number of countries are exploring or implementing new national accounting frameworks that complement traditional statistics. The wellbeing approach is highly relevant for tourism as the shift towards measuring all types of capital, as well as non-materialistic indicators, raises questions about how tourism can make a positive contribution ${ }^{2}$.

Changes in national accounting frameworks are not sufficient in themselves, but they can help to rebalance economic growth with other outcomes. For tourism, this could mean a substantial shift away from focusing on visitor arrivals and expenditure (amongst others achieved through government investment into marketing) towards managing tourism impacts. At present, most if not all destinations spend considerably more funds on promoting their region than on programs that help increase the net value of tourism (e.g. by supporting local supply chains), managing natural environments, and building inclusive and fair partnerships with local stakeholders (see below). What would happen if all signatories to the Paris Agreement were to agree on a moratorium on tourism marketing until verifiable absolute reductions in tourism GHG emissions are recorded? Whilst this would not stop businesses marketing, it would free up public sector resources to help transform infrastructure, technology and tourism systems to achieve low-carbon tourism.

Already, the industry's focus on growth has come under scrutiny as an increasing number of destinations suffer from excessive visitor pressure (WTTC \& McKinsey \& Company, 2017). Societal backlash, reductions in visitor experience quality and environmental degradation have become more visible and are exposed through both mainstream and social media. Whilst management options exist and system efficiencies can be enhanced, the overall question of whether the level of tourism growth is desirable remains unanswered. As such, the 'overtourism' phenomenon could be a 'canary in the coal mine' of future reticence against tourism as a major carbon contributor. Important lessons currently being learned in the overtourism debate may be helpful for managing the slowing of tourism's growth in response to a climate crisis (Becken \& Carmignani, 2019).

\section{Institutionalised structures and interests}

\section{The power of elites}

One major hurdle to decarbonising tourism is that the belief in growth has been institutionalised, and concomitant structures provide increasing power to a small number of key players who support the prevailing ideology. This 'elite' has successfully built a system that promotes their interests and provides little opportunity for alternative views. This can be explained by Social Dominance Theory (Sidanius \& Felicia, 1999), which relates to the hierarchical way in which most societies are structured. Bennett $(2017$, p. 1) summarises: "Put simply, the theory states that people with power will always seek more of the desirable things in life (as they see it) at the expense of their subordinates." Dominating paradigms are by definition self-enforcing and will not change unless, for example, high level frameworks (e.g. a global agenda with implementation powers) will force them to do so.

More recent research has linked the concept of social dominance to environmental action. It was found that people who score relatively high on the dominance scale (i.e. supporting stratified, less equal societies and focusing on self-enhancing values) were less likely to act altruistically and reduce their carbon footprint (Milfont et al., 2017). Indeed, research by Parker et al. (2013) in Chile established that even those members of the elite who actively engaged in discourse on climate change, demonstrated little interest in actually supporting systemic changes.

\footnotetext{
${ }^{2}$ See Pollock (2015) for ideas on linking conscious travel, flourishing and well-being.
} 
Changing existing political or economic structures is not in the interest of current decision makers, as - by definition - this might result in a loss of power (Kilbourne et al., 2002). If people with higher social dominance orientation are more likely to strive for leading positions, it then follows that decisions made 'at the top' are less likely to be pro-environmental and pro-social. This has significant implications for the potential for change.

\section{Tourism peak bodies and their 'accomplices'}

There are two key peak bodies in tourism. The UNWTO, as the United Nations agency responsible for tourism, focuses on public sector policy and intergovernmental agreements. In their own words "UNWTO promotes tourism as a driver of economic growth, inclusive of development and environmental sustainability" (UNWTO, 2019). The WTTC represents the industry and is a global body that lobbies for private sector interests. Their agenda is "to raise awareness of Travel \& Tourism as one of the world's largest sectors, employing 1 in 10 people and generating approximately $10.4 \%$ of global GDP [Gross Domestic Product]" (WTTC, 2018b). Both organisations are fully embedded in the growth paradigm. In addition, they equally depend on membership as key sources of income, and accordingly are driven by the (perceived) needs of their members (Figure 1).

The majority of the 158 UNWTO member countries are emerging economies. Not surprisingly these countries believe that tourism growth will result in major development benefits. Specific programs by the UNWTO support such causality (e.g. STEP or Sustainable Tourism for Eliminating Poverty). Furthermore, the dominant narrative in UNWTO communication material (e.g. UNWTO \& Griffith University, 2017) and data outputs (e.g. UNWTO Tourism Barometer) cements the notion that increases in arrivals will increase GDP, reduce poverty and decrease inequality. Critical assessments that provide counterpoints to this argument are absent from tourism discussions (for one exception see Dwyer, 2018), although interesting insights can be found elsewhere ${ }^{3}$. Jackson (2018), for example, explored the complex relationship between GDP and equality. In the case of the United Kingdom, welfare inequality in society has risen significantly despite increases in economic activity. The unequal distribution of income leads to a wide range of other issues (e.g. richer people live a healthy life for 20 more years than deprived people), including substantially higher carbon footprints (30 times) of rich versus poor households).

The reinforcing circle of joint agendas between members and the peak organisation is similar for the WTTC. Here, members and in particular directors of the board typically represent large tourism corporations that operate under a shareholder model where maximising financial return is the priority. Whilst some companies are investing in Corporate Social Responsibility initiatives, major shifts in business models are rare. Thus, sector representatives naturally advocate models and policies that remove barriers to growth, and they tend to support those mechanisms that reduce carbon emissions but not at the expense of tourism growth (e.g. CORSIA or industry's preference for efficiency-based carbon reduction targets).

Other players in tourism include non-governmental organisations (NGOs) and academic institutions (Figure 1). Whilst these can seemingly act freely in their roles as advocates, thinkers or as the 'conscience of society', they are just as caught up in the system as the main players. Obtaining funds for campaigns or research is highly dependent on aligning with the agendas of donors or other types of sponsors. Monbiot (2018) claimed that academic institutions have fallen victim to the same growth imperatives and commercialisation agendas as many businesses. Especially in countries where Universities are expected to generate positive financial returns, obtaining research funding by academics may take priority over ethical concerns. Monbiot provides pertinent examples from the fields of neuroscience and advertising (including research on how to convince people to minimise scepticism towards companies' sustainability reporting).

In other situations, academics, consultants or NGOs may use 'trojan horses', where the proposed project meets the priorities of the sponsor, whilst incorporating improvements in sustainability (if not already part of the project), knowledge generation, or other intangible benefits that rationalise

\footnotetext{
${ }^{3}$ Hawken (2010) comments on capitalism noting "we are stealing the future, selling it in the present, and calling it gross domestic product" (p. xxii).
} 
participation in the activity. In general, however, it appears unlikely that key players support (or publish, see Bendell, 2018) work that revolutionises the current system, structures, ideologies, and mechanisms. Hence, securing significant resources that help "overthrow a system that demands we participate in environmental degradation" (Bendell, 2018, p. 13) is inherently difficult.

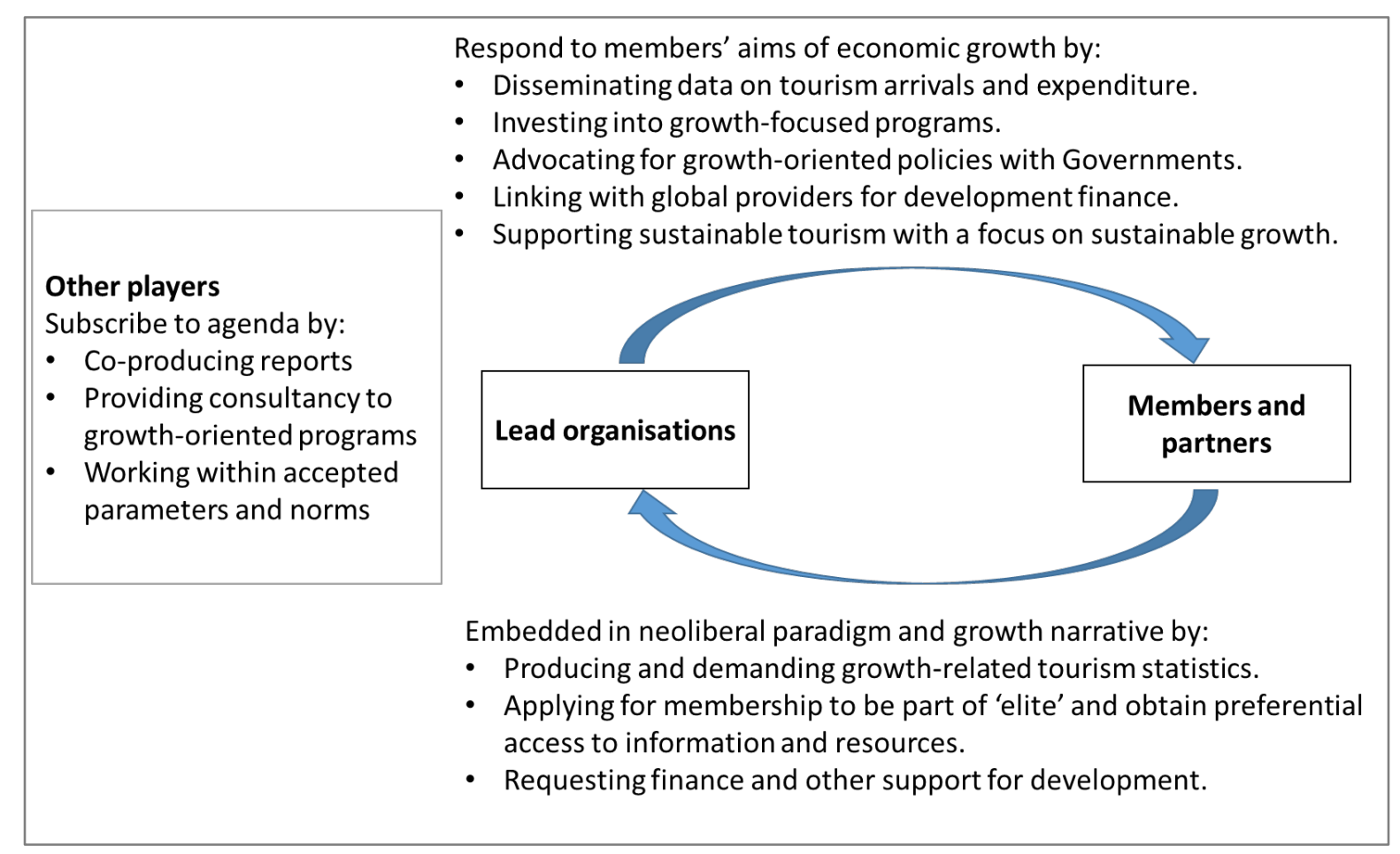

Figure 1. The re-enforcing circle of the prevailing growth paradigm between key players (Source: author).

\section{Overcoming the institutional conundrum}

One way to overcome systemic lock-in is to measure 'progress' differently. As already introduced in the discussion of the growth related conundrum, current measurement systems rely on a small number of economic indicators. For national economies this is usually GDP, and for tourist destinations it is numbers of arrivals and dollar expenditure. Accordingly, the Key Performance Indicators (KPIs) of top level decision makers reflect these measures exactly - leading to a volume-based approach to tourism that leaves little space for more comprehensive assessments of costs and benefits. If, for example, the performance of managers of national tourism boards were also measured on the basis of the carbon footprint that their industry ${ }^{4}$ adds to national climate obligations, the task of optimising arrivals with resource use would become much more complex.

Providing enhanced knowledge of tourism impacts and opportunities could lead to an alternative possible steady-state (Hall, 2010) - approach to tourism planning and governance. Developing more inclusive governance structures would give a voice to community members that are affected by tourism but not presently heard in discussions on airport expansions, hotel developments or other infrastructure projects. Sustainable tourism governance (UNWTO \& Griffith Institute for Tourism, 2017) would seek to balance economic, social and environmental needs. Reducing GHG emissions has to be a key goal. Understanding the political economy is one important step in shifting from the current neoliberal paradigm to a more sustainable paradigm. This shift would also involve a move

\footnotetext{
${ }^{4}$ This problem is not unique to tourism, however, the difference is that tourism emissions are usually less visible (e.g. compared with agriculture or mining that form part of the System of National Accounts and are clearly identified in national GHG inventories) and at the same time fast growing. Hence, in terms of reducing exposure to future carbon risks, countries might well become aware of the increasingly important role tourism is playing in achieving or failing NDCs under the Paris Agreement.
} 
from a shareholder oriented business model to one that creates value for multiple stakeholders (i.e. communities, employees and others involved in, or affected by, the production process) (Dwyer, 2018). Whether the emergence of social enterprises (Pollock, 2015) will sow the seeds for such a shift deserves further research.

Another way of disempowering existing elites is by disruption. The rise of the sharing or collaborative economy has shown how existing structures and sectors can be shocked - and potentially changed by new ways of matching supply and demand (Gössling \& Hall, 2019). In some cases this has created new elites. Using digital technologies, innovations are emerging across various industries. Recent examples include blockchain based peer-to-peer energy distribution networks (Verv), an internet based platform to help users of electric vehicles (EV) locate suitable public charge points (Zap-Map), and collectively owned energy plants such as wind farms (Ripple Energy) (Greenhouse, 2018). Many of these disruptions create grass root opportunities for people and reduce the monopoly-like structures created by large corporations. Decarbonisation is built-in, and increasing demand shifts market share towards those new economies, whilst at the same time forcing traditional players to adapt to new models.

\section{Who makes policy?}

Politicians avoid negative outlooks (or panic, Bendell, 2018) and policy making often follows the storyline of unchanged success. As a result, policy is driven by 'desirable futures' (Peeters et al., 2018). The complex web of data, and vested interests and policy has been explored in the context of peak oil. Becken (2015) observed that geopolitics, lobby groups, governments and oil companies collude in ways that create impressions of abundance and new discoveries, and suppress counter narratives of oil as a risky sunset industry. Possibly, the situation is not so different for climate change and the global travel and tourism industry, noting that tourism is inherently related to 'positive messaging' (centred around a hedonic industry) and also escapes many existing systems of monitoring and governance due to its multifaceted and fragmented nature ${ }^{5}$.

\section{Policy for industry}

The shortcomings in climate action to date are not the lack of solutions but the absence of political will (The Club of Rome, 2018). In recognition of impending environmental disaster and to reduce business risk (especially in tourism where every season presents a new risk), neoliberal governments have begun to intervene more directly. The notion of Green Keynesianism (Mann \& Wainwright, 2018) involves the State as a key actor in climate finance and generation of 'welfare', but it achieves this by using conventional (fiscal) approaches. Whilst seductive (do what we are doing, but "greener" and "more equal"), Mann and Wainwright remain sceptical, noting that "this regulatory response to capitalism's planetary challenges is likely to further concentrate power and resources in the hands of elites" (2018, p. 121).

In the meantime, tourism organisations have an interest in maximising the 'size' of the sector so as to legitimise and elevate the importance of their mandate. A larger sector guarantees greater influence and financial support. Such thinking is implicit in one of UNWTO's recent (2018b) press releases, "2018 Poised to Advance Tourism's Leadership among Top Global Economic Sectors", celebrating the significant growth in global tourism. The greater 'muscle of leadership' will likely influence national and international policy and in a self-fulfilling (growth) prophecy lead to further tourism investment. However, Scott and Gössling (2015) criticised that tourism projections presented by peak bodies provide little guidance on how to manage the sustainability implications of such growth. To address this, UNWTO (2017) has initiated the project Towards a Statistical Framework for

\footnotetext{
${ }^{5}$ The Tourism Satellite Account has been created to address this issue from an economic perspective. The method involves extracting tourism components from the standard National Accounts to provide insights into tourism's contribution to the national economy. Key metrics, such as contribution to GDP, value add, and employment are used, amongst others. The UNWTO (2017) is exploring ways for extending such an approach to environmental accounting. In the meantime it remains difficult to discern the carbon impact of tourism, increasing the challenge of effective policy making.
} 
Measuring the Sustainability of Tourism (MST) which will help monitor the sustainability dimensions of tourism.

Industry-driven policy is nowhere more evident than in the aviation industry's CORSIA. The scheme is the industry's response and contribution to the Paris Agreement: it was developed jointly by ICAO and IATA, both of whom work closely with the airlines. Whilst representing a substantial achievement in bringing together a carbon intensive industry, the CORSIA represents, in the first instance, a license to grow (see Lee, 2018). Emissions from international routes and between participating countries will have to be offset from 2021 to the extent that they exceed the 2020 baseline on respective routes. A substantial amount of revenue will be generated to support carbon offsetting projects. The flaw is that the purchase of one carbon credit (i.e. 1 tonne of CO2) to offset the additional emissions of another tonne of $\mathrm{CO} 2$ into the atmosphere does not result in net reductions, but simply achieves a net zero gain (Becken \& Mackey, 2017). Further problems on the integrity of credits and double counting remain unresolved ${ }^{6}$, leading Lyle (2018) to argue that more effective decarbonisation of aviation could be achieved by including international aviation in national policy schemes. Considering the significant role aviation plays in tourism's overall footprint (Peeters et al. 218), effective decarbonisation is of critical importance.

\section{Globalisation of decision making}

At a local level, the problem of overtourism has brought to light the inability of decision-makers to withstand the lure or pressure of exogenous interests. Over 30 years ago, Keller (1987) argued that the development cycle of tourist destinations often entails a move from local entrepreneurs' capital to an increasing level of influence from outside the destination as it grows. Whilst this brings fresh capital, it comes at the price of lost control by the local communities. Many of today's destinations are subject to decision making by airlines, cruise ship companies, developers, investors, and other international operators - epitomising the above mentioned trend of increasing influence that corporations have on policy and decision making, and the concomitant erosion of democracy (Dwyer, 2018). Rules of engagement tend to be determined by the external parties rather than the local players. A lack of authoritative and reliable data on impacts means that local actors are not fully empowered to assess their situation and develop different pathways. When tourism profits are repatriated to overseas investors, destinations are left with little revenue but mounting (external) costs from tourism.

\section{Integrated and participatory approaches}

Providing frameworks that help measure genuine progress (i.e. well-being) will drive new types of policies. Rectifying market failures (Simmons, 2017) ${ }^{7}$ but also providing options for 'nudging' people into alternative choices (e.g. the congestion charge in London) is a good start (Hall, 2013), but will not be enough. By definition nudging does exactly that - nudge. It can perhaps be seen as a precursor that fits comfortably within neoliberal behavioural economics, but also provides a basis to more radical and integrated policy. Whilst there is little analysis on climate change policy for tourism specifically (Becken \& Clapcott, 2011), it appears that most climate-related policy comes from environment (or perhaps transport) ministries. Often, such policy pursues quite different goals ${ }^{8}$ to tourism policy developed by tourism ministries. Joined up thinking and a more deliberate approach to climate-tourism policy is important to ensure a fair contribution of tourism to carbon reduction targets, but also accommodate the specific needs of the industry. Acknowledging the exposure to carbon risk, for example, would help destinations assess their relative vulnerability and opportunities

\footnotetext{
${ }^{6}$ One problem relates to additionality, i.e. demonstrating real and additional reductions in GHG emissions. In a study on the effectiveness of the Clean Development Mechanism - one major path to generate carbon credits Cames et al. (2016) found that " $85 \%$ of the projects covered in this analysis and $73 \%$ of the potential $2013-2020$ Certified Emissions Reduction (CER) supply have a low likelihood that emission reductions are additional and are not over-estimated" (p. 11).

${ }^{7}$ Mann and Wainwright (2018) note that the notion of market failure is symptomatic of liberal capitalism, which does not question markets per se, but acknowledges their potential failure. Accordingly, they note that the prevailing instruments of emission trading schemes, carbon offsetting, catastrophe bonds and similar are marketdriven responses that ultimately may be insufficient to address the root causes of the problem.

${ }^{8}$ The example of airport extensions versus national climate policies highlights this conflict.
} 
to manage risk. Recent analysis by Becken and Shuker (2018) demonstrated that carbon risks differ hugely for different types of destinations, with island states generally being most exposed.

\section{Incremental change}

One complex decarbonisation challenge is that of incremental change. It brings improvements that are modest and fall short of counteracting the rapid growth of the sector. Examining tourism's carbon footprint between 2009 and 2013, Lenzen et al. (2018) found that the 5-year increase in tourism activity of $30 \%$ has more than outweighed the reductions in carbon intensity of $12.9 \%$ in the same timeframe. The result was a $14 \%$ increase in tourism's emissions over those five years.

\section{Increasing energy efficiency}

Improving technology is an integral part of the dominating neoliberal paradigm. The tourism industry has benefitted from diverse technological innovations that helped reduce the carbon intensity of delivering tourism-specific services. Well-known examples for tourist accommodation and other buildings include energy-efficient lighting, motion sensors, Building Management Systems, building design and new materials (Becken, 2013). ICAO (2016) report on a range of technological options to improve the efficiency of aircraft, including weight reductions, pilot training, improved routing. Transformational change through electric and hybrid planes is also discussed, but there are serious constraints (e.g. battery technology) and timeframes are long. Elsewhere, improved use of technology provides substantial potential to increase the efficiency of current transport systems (e.g. Amadeus' (2017) tools for reducing emissions at airports).

Tourism has seen an increasing number of 'success stories' (e.g. WTTC's Tourism 4 Tomorrow awards), but as a whole changes remain marginal with limited evidence on whether or not small efficiency gains are overcompensated through the well-known rebound effect ${ }^{9}$. Sustainability reporting creates a perception of widespread positive impacts, even though corporate reports or sector-wide data rarely reveal comprehensive insights into performance. In other words, present reporting is highly selective.

One example is the report "Tourism and the Sustainable Development Goals - Journey to 2030" by the UNWTO and UNEP (2017). By analysing the sustainability reports of 60 tourism corporations the publication provides insights into those Sustainable Development Goals, where tourism can make a positive contribution. Whilst inspirational action is presented, the assessment fails to quantify where action is inadequate or where the existence of tourism could even undermine the success of SDGs. For example, increasing levels of GHG emissions from tourism will exacerbate the vulnerabilities of already disadvantaged groups. This type of approach reflects a well-known observational bias, the socalled streetlight effect ${ }^{10}$, where information is not researched based on need or validity but on other factors. For tourism, as for other industries, there is a risk that a small number of positive case studies could be used to legitimise the status quo, or even be seen as a social/political license to grow. Accusations of greenwashing might follow ${ }^{11}$ (Vos, 2009).

\footnotetext{
${ }^{9}$ The rebound effect relates to the observation that improving efficiency might lead to greater use of this resource. In the context of motor vehicles, for example, it was found that a $5 \%$ increase in fuel efficiency leads to a $2 \%$ drop in fuel use (not $5 \%$ ). The reason is that vehicle users are now driving faster or further (Wang, Han \& Lu, 2016).

${ }^{10}$ The streetlight effect goes back to a joke that has been told in several contexts and cultures: A drunk man is searching for something under a streetlight in the middle of the night. A policeman comes by and asks the man what he had lost. The drunk answered he had lost a \$2 bill (or his keys in other versions), and the policeman helps searching. After a while, he asks the drunkard "are you sure you lost it here?" "No", said the man, "I lost it in the park, but the light here is better".

11 'Greenwash' covers the spectrum of deliberate distortion ("talking green while lobbying brown", Lyon, 2018, p. 1), systemic failures (e.g. positive action with non-material impact), and being blinded by our own 'story telling' and desire to improve the image of the industry and the value of individual brands (Vos, 2009).
} 


\section{Moving beyond 'tinkering around the edge'}

Radical investments are required to achieve the reductions outlined in the ITP (2017) science-based targets report. Businesses will have to move beyond 'low hanging fruit' and capital investments that have Return-on-Investment horizons of less than one year. This requires not only commitment at the top level of the company, but also buy-in from shareholders, staff and customers. Policy support to incentivise significant low-carbon investments and penalise old equipment and infrastructure would help enable the transition. In addition to government policy, increasing pressure is coming from investors. A recent announcement by a group of 415 investors, insurance companies and superfunds at the Poland Conference of the Party (COP24) summit calls on governments to accelerate climate action to provide a suitable framework for investment into cleaner technologies (UNEP Finance Initiative, 2018).

In addition, a greater focus on integrating technology with human behaviour is required (see below). Typically, new technologies are implemented by engineers who focus on the technical aspect rather than on how people might use the technology. There is often limited communication between the operations/engineering departments and other areas of the company (e.g. customer service, staff training, marketing) (communication with environmental managers/engineers at EarthCheck Inner Circle meetings, and see Bohdanowicz et al., 2011). Hence, technological innovation is rarely accompanied with service sector or management innovation. Research within and beyond tourism clearly shows that decarbonisation can only be achieved by a combination of both.

\section{Unsustainable production and consumption}

\section{Efficiency instead of conservation}

Improving energy efficiency (even radically, for example passive solar building design) will not in itself result in zero emissions, as there is always a remaining - albeit decreasing - quantity of emissions produced as a result of an activity. Thus, resource conservation is another important avenue to achieve decarbonisation. Energy conservation essentially refers to activities that reduce the amount of energy service required, either through tourist behaviour or managerial improvements (Warren \& Becken, 2017). An example would be to walk instead of using a car or even using public transport. Moving from efficiency to conservation considers both human and non-human elements in ecoinnovations and provides a more comprehensive solution space than technology alone (Buijtendijk et al., 2018).

An increased focus on behaviour instead of efficiency-based approaches is even more important given that investments into capital intensive technology and infrastructure lock the sector into the existing path for a long time (Dwyer, 2018). Major road or airport infrastructure projects, for example, demand substantial use over many decades to generate financial or social returns on investment. The purchase of present-day aircraft, for example, results in the basic combustion engine technology being used for at least another 20-30 years (even if it is now more efficient). Along with capital investment, come investments into labour markets (e.g. pilot training) and business models that are difficult to change.

\section{Economic incentive structures}

Why is it so difficult to change? Often, behaviours that are desirable appear to create a disadvantage, when those that may be less beneficial are incentivised. Perverse incentives that create economic behaviours that undermine the environment or well-being have been extensively researched, including in the context of carbon emissions such as disproportionally high subsidies for fossil fuels.

Economists are occupied with the question of how much it will cost to address climate change (e.g. Becken \& Carmignani (2019) assume $>1 \%$ of global GDP or US $\$ 300-400$ billion per year), for example as a result of investing into development and implementation of new technologies and changed consumption patterns. The bigger question, however, is to understand vested interests that are associated with current technologies, behaviours, and systems and economic opportunities for a new 'ecology of commerce' (Hawken, 2010). At present, for example, the global advertising budget amounts to US\$ 584 billion in 2017 (tourism included) (Statista, 2018), promoting consumption and 
possibly undermining climate goals. What if some of this budget was redirected towards climate change mitigation or development of new economic systems? Clearly, present systems are designed to encourage people to consume more, rather than getting them to consume differently or less. Evidence come from all spheres of life, including two-for-one deals in supermarkets, 'upsize me' options in fast food outlets, and customer loyalty programs.

Airlines have been particularly successful in creating frequent flyer programs that not only create brand loyalty ${ }^{12}$ but reward unsustainable behaviour with considerable access to privilege (e.g. lounges, extra luggage) and opportunities to fly more when converting points. One example is a campaign by Aeroplan ${ }^{13}$ in 2010 , which involved a 6-month educational program targeted at four million loyalty members. To encourage participation, people were given the opportunity to redeem miles for carbon offset, and each redemption was automatically entered in the draw for winning additional 250,000 Aeroplan Miles (Offsetters, no date) - ironically providing a counterpoint to the educational purpose of the campaign. To the knowledge of the author, there is no system in place that encourages people to fly less, or - at least - provides recognition points every time a customer offsets their emissions.

Concepts such as 'sufficiency', 'frugalness' or 'rationing' remain marginal in the tourism discourse (Hall, 2013), and radical shifts are unlikely to be achieved using market-based instruments (Bailey \& Wilson, 2009). Indeed, Bolderdijk and Steg (2015) suggest that financial incentives in particular (e.g. some hotels now offer a dollar voucher for declining room service) can be problematic. Money puts people in a particular frame of mind and undermines the value of the message, namely to make a positive contribution to the environment. The business frame resulting from a financial incentive reduces the power of self-persuasion and esteem generated by an altruistic and intrinsically rewarding task.

For tourism the notion of 'conserving' might be more challenging than for other industries, given its hedonic nature and the core promises around pleasure and indulgence. Travel generates social status and the age of social media has provided a new vehicle to fuel and reinforce the role that (exotic) holidays, play in building or communicating identity (Peeters et al., 2018). Facebook and Instagram have been particularly influential due to their popular function of sharing images and videos.

\section{Catalysing behavioural change}

Exploring energy transitions more broadly, Steg, Perlaviciute and van der Werff (2015) note that changing behaviour requires three ingredients, namely knowledge and the understanding of why change is necessary, the motivation to change, and the ability to implement different behaviours. Receiving rewards, personal benefits or pleasure from behavioural change is likely to incentivise new behaviours (e.g. walking and perceived associated health benefits). In the tourism context, this means that low-carbon tourism experiences should consider the hedonic aspect of travel and be designed in a way that maximises positive emotions (Warren, Becken \& Coghlan, 2016). Exceptional and memorable experiences do not have to rely on the (excessive) input of resources; especially in a service industry where human interaction (e.g. a guided tour, wellness treatments) constitutes the core of the product. The value of an activity can be decoupled from resource use.

Change can happen at multiple scales, including destination choice (see below) and transport modes, but also other social practices related to tourism. Conceptualising staying at tourist accommodation as a social practice (including routines such as cooking, heating, hygiene), Warren et al. (2018) identified that a change in available amenities, an improvement in the level of customers' know-how, and a shared meaning (e.g. to use the fireplace to be warm and renewable) can result in significant

\footnotetext{
${ }^{12}$ Note that many low-cost airlines do not operate frequent flyer systems. One reason is that customer loyalty is secondary to low prices in attracting travellers, especially those segments that make short-term decisions that are driven by price rather than product.

${ }^{13}$ Originally created by Air Canada in 1984, Aeroplan is now a coalition loyalty program (owned by Aimia) that is used by multiple airlines, credit cards and retail companies. Aimia (https://www.aimia.com/about-aimia/) has promoted carbon offsetting to its customers in multiple campaigns and provides calculators and other tools.
} 
resource savings. Thus, by modifying infrastructure, competency and understanding people's emotions (Shove, Panzar \& Watson, 2012) it is possible to achieve tangible shifts in behaviour.

Change must go beyond merely adjusting social practices. It requires significant modifications of people's lifestyles, possibly concomitant with the loss of privileges, indulgence and convenience. Kashtan (2015) talks about natural abundance versus artificial abundance (e.g. surplus that goes beyond what we actually need) and how increasing levels of abundance for some have led to entitlements that are built on growing inequality but difficult to forgo for those who have them. She argues that humans "cling to privilege because it's been given to us as a substitute for a real need" $(2015$, p.1), noting that people have replaced joy for convenience, money for freedom, and success for meaning. Research to date has failed to translate these insights into the tourism context.

When humans have to change they feel threatened. Neuroscientists have studied how our brain rewards system programs us to reduce threat and maximise positive outcomes. The mechanism of resisting change is known as the 'walk towards, run away' theory (Gordon, 2000). Climate change is a particularly pertinent example of a threat. At the same time, it is also likely to remove the extent of choice we have to change our behaviour. Recognising the definite and devastating nature of climate change is likely to involve a phase of 'grieving' where people have to come to grips with the loss of their personal entitlements, and wider collapse of society or ecosystems as we know them (Bendell, 2018).

\section{Distribution of tourism}

The geography of travel is a major factor in decarbonising tourism. The distribution of tourism sits at the core of GHG emissions, inequality and tourism as a development tool.

\section{Tourism epitomises inequality}

Tourism's growth in recent years is due to the opening up of some countries (e.g. China) and the broader 'democratisation' of travel. Data from the Global Sustainable Tourism Dashboard (2018) show, however, that travel is still a privilege of the rich (Peeters \& Landré, 2012). Over half of global outbound travel comes from ten countries. Likewise, over half of tourism arrives at only 10 recipient countries. The top ten outbound and inbound countries are almost the same. This indicates that essentially half of global international tourism occurs between 10 countries, and within these a significant share comes from a "hypermobile elite" (Peeters et al., 2018, p. 11). The share of outbound travel from Least Developed Countries and Small Island Developing States (SIDS) is less than 2\% of international travel.

The argument that tourism redistributes wealth and can help alleviate poverty is therefore not completely true - at least at a global scale. At the local level, of course, a considerable number of successful case studies demonstrates that there can be tangible benefits from tourism development. Especially in small countries (e.g. SIDS) comparatively low levels of tourism activity can generate substantial positive impact. However, the amount of about 600 million tonnes of $\mathrm{CO} 2$ from global passenger aviation cannot be fully justified with development rationale.

Tourism-induced or not, it is an agreed aspiration to assist less developed countries in their economic development. This includes in particular aspects of equity and equality (see also UN Sustainable Development Goals). It is therefore expected that an increasing number of developing countries will want to participate in global travel. To stabilise or reduce emissions, this would then require a reduction and contraction in travel by the traditional markets. This is very unlikely for reasons already discussed earlier, including the business interests of large companies that are headquartered in these source countries and existing privileges held by citizens of developed countries that are difficult to give up.

\section{New markets and destinations?}

Overtourism has made it apparent that some destinations face unacceptable crowding. Since reducing the volume of tourism is apparently not an option, the proposed solution is to disperse travel and develop new destinations. Major international and donor-funded projects are underway to 'build' new 
destinations (e.g. Myanmar, Vanuatu, Rwanda), and this will bring with them an ever extending network of global tourist flows. Developing long-haul destinations may not be desirable or realistic in the long term (Becken \& Carmignani, 2019). Peeters et al. (2018) present a scenario for tourism in 2100 where growth in terms of jobs, revenues, trips and visitor nights will be comparable to a baseline scenario, but a spatial redistribution occurs away from distant places towards shorter haul destinations.

The role of domestic tourism will increase, and recent attention on this segment represents an early sign of shifting perceptions and prioritisation. Already, domestic tourism contributes $73 \%$ of all tourism expenditure globally (WTTC, 2019). "Staycation" constitutes a major market trend (e.g. Pyke et al., 2016), resulting in reduced environmental costs but also delivering greater well-being for travellers. The slow travel concept (Buckley, 2011) provides potential for more sustainable and experience-rich forms of tourism that do not rely heavily on carbon. Slow travel can be integrated with locally grown food, which can be associated with lower carbon footprints when farmed appropriately and transported less.

In addition to new countries opening up for tourism, there is scope for considerable investment into new attractions at established destination countries. The idea is to reduce pressure at hot spots and at the same time spread tourism benefits further. Planned well and designed with sustainability in mind, new destinations could 'pull' the right mix of visitors that contribute to local or national well-being goals (Dwyer, 2018). There is a risk that dispersal increases the carbon footprint of tourism when people have to travel further to get to these new places.

The solution of dispersal requires more thought in relation to transport related emissions ${ }^{14}$. An example is the Victoria Falls in Zimbabwe/Zambia where an international airport connects visitors to four countries. Funded with Chinese money, the airport is currently expanding to more than triple its capacity. Is further growth at already heavily visited places sensible or will Victoria Falls become a new gateway for visitation into further-away parts of Africa? Is it possible to grow the periphery without growing the core and without increasing carbon emissions? Balancing goals of equality, regional development, crowding, and emissions will have to be a major focus in policies designed to decarbonise tourism. Considering new models of tourism governance and moving from a growth to a stewardship orientation are essential steps in ensuring sustainable low-carbon destinations (Dwyer, 2018).

\section{Concluding Discussion}

The purpose of this paper was not to provide a detailed assessment of tourism's carbon footprint (e.g. see Lenzen et al., 2018) but rather to identify systemic mechanisms that act as barriers to future decarbonisation. Accordingly, six challenges were presented that in combination could appear to be a 'mission impossible' for decarbonising tourism. The current system of drivers and challenges is shown in a simple causal loop diagram in Figure 2, noting that the complexity of tourism's carbon emissions should be further researched using systems dynamics modelling. In its basic form, the Figure shows that most drivers lead to an increase in tourism's CO2 emissions. Importantly, the system visualised here is set against the context of the Paris Agreement and other policy frameworks (e.g. CORSIA) that seek to mitigate climate change. How these frameworks interact with the drivers shown here is a complex question and requires a more detailed assessment of policy effectiveness and mechanisms.

One major hurdle is the legacy of, and belief in, ongoing considerable growth of the industry (Challenge No 1). Growth does not just happen - tourism is purposefully promoted and supported by a set of intertwined mechanisms that all link through a common agenda anchored in neoliberalism, market forces and technology-belief that address upcoming 'headwinds' (Bailey \& Wilson, 2009).

\footnotetext{
${ }^{14}$ Lane (2017, p. 16) contends: "There is an urgent need for more and deeper research into the mechanics, politics and outcomes of sustainable destination management".
} 
One important step for tourism, therefore, is to recognise the challenge that growth brings with it and what this means for the Paris climate goals ${ }^{15}$ (Gössling et al., 2010; Lee, 2018).

The institutionalisation of interests (Challenge No 2), including those related to capital, is closely linked to liberal policymaking that often puts industry interests at the centre (Challenge No 3). One hurdle is that current holders of power and influence have limited interest in investing into alternative approaches, be they new types of data (e.g. see Global Sustainable Tourism Dashboard, 2018), different accounting frameworks for tourism impacts (e.g. UNWTO, 2017), or newly defined manager KPIs.

Incrementalism (Challenge No 4) and a focus on technological solutions (Challenge No 5) mean that radical improvements are lacking. Clearly, current approaches of 'easy wins' must be enhanced by radical service innovation and behavioural change. Resource conservation in itself (i.e. not doing something) may not intrinsically appeal to industry, as conservation may imply less commercial activity. Changing behaviours could also affect the geography of travel (Challenge No 6). Current patterns and trends (further-away) of travel result in growing GHG emissions, and solutions of dispersal may exacerbate these.

${ }^{15}$ For a recent assessment of CORSIA's effectiveness see Lee's (2018) paper for the UK Department for Transport. 


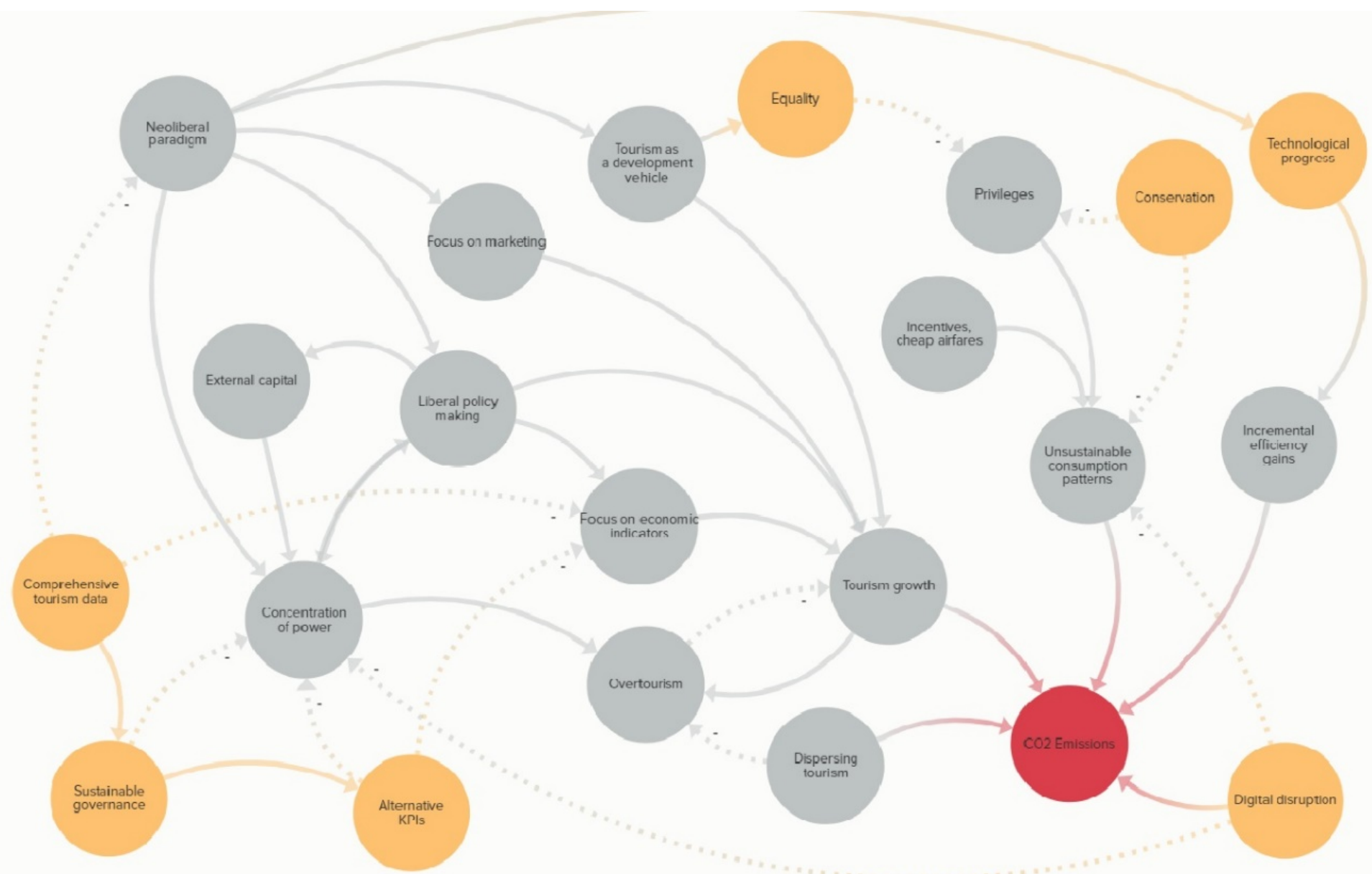

Figure 2 Visualisation of key drivers influencing carbon emissions from tourism. The dotted links indicate a negative feedback loop. Change factors are highlighted in yellow. (Source: this diagram used Kumo software). 
Tourism businesses are risk adverse and the sector as a whole rarely takes a future-oriented approach. As noted by Scott and Gössling (2015), the sector has not fully engaged with scenario planning, including with outputs from existing scenarios in sectors such as energy, development, technology or ecosystems sciences. Rather than accepting the imperative of net zero emissions by 2050 and working backwards on how to achieve this, tourism still takes a position of extrapolating past trends and hope they somehow converge with decarbonisation goals. They will not.

There are several 'shifters' that have the potential to trigger systemic change, however, as highlighted in yellow in Figure 2, they are at the margin. They are comparatively small in size and influence (see earlier note on the 'muscle' of the global advertising industry). Some of the shifters could be strengthened, for example by Academics who provide critical thinking and evidence, NGOs who advocate for change, or entrepreneurs who seek new types of business models. For example, new service industries can develop around activities that require little energy input and draw on existing resources (e.g. see the guiding sharing platform LocalYokl, 2019). Disruption through new grass root initiatives is one avenue for change.

A major redistribution of financial flows is necessary to shift from volume-based growth to valuebased growth (Dwyer, 2018), and more research is needed to understand what this actually means. Better reporting and disclosure (including a third party audit and certification) are important to avoid 'greenwash' and provide guidance on 'what works' and where genuine progress is made. In addition to voluntary reporting of climate activities, companies could be mandated to make public their political (lobbying) positions. Such enhanced transparency would increase trust in the industry and reward leaders.

In the meantime, change may start at the bottom and be driven by increasingly conscious consumers, entrepreneurs, innovators and early adopters in the tourism industry. Responsibility falls on all of us, as ultimately it is the consumers who demand travel. Consuming less or differently sends important signals to both the private sector and policy makers. Greater uptake of closer-to-home holidays, certified products, responsible practices, and personal climate action (e.g. offsetting, purchase of lowcarbon products) is already being noted and beginning to marginally influence production. To trigger broader change, however, sustainable consumption patterns will have to be enhanced with greater involvement in civil society advocacy. A more effective system for the governance of tourism as an activity and as an industry will have to emerge. Possibly this would rely less on sector organisations, but involve local participation and representation of a wide range of stakeholder groups who work with or alongside local government (Pollock, 2015).

Finally, and reminding of the need for intellectual leadership and critique, academics have to collaborate more effectively on solutions that help overcome the challenges laid out in this paper. As Lane $(2017$, p. 10) noted, "Sustainable tourism was [...] created by academics, and academics have been enthusiastic discussants and researchers, but they have not -so far-succeeded in driving the implementation of sustainable tourism". Research and innovation with industry and for industry, using a wide range of tools and techniques, will be needed to address the complexities of decarbonising the tourism system. This may involve breaking the dynamics of mainstream paradigms shown in Figure 1. Tourism researchers will have to dramatically increase collaboration with other disciplines and non-academic partners. How that could be done will be the subject of a further paper that focuses on solutions. It will not be easy, and it could require academics to learn some new and demanding skills. 


\section{References}

ABC (2016). WA Labor tourism pledge to cut red tape, boost marketing. 14 April. Available (30/11/18) https://www.abc.net.au/news/2016-04-14/labor-tourism-plan-unveiled-withpledge-to-cut-red-tape $/ 7326778$

Amadeus IT Group (2017). Global Report 2017. Available (30/11/18) http://www.amadeus.com/msite/global-report/2017/en/home/

Bailey, I. \& Wilson, G.A. (2009). Theorising transitional pathways in response to climate change: technocentrism, ecocentrism, and the carbon economy. Environment and Planning A, 41, 2324-2341.

Becken, S. (2015). Tourism and Oil: Preparing for the Challenge. Cleveland: Channel View Publications.

Becken, S. (2016). Evidence of a low-carbon tourism paradigm? Journal of Sustainable Tourism, $25(6), 832-850$.

Becken, S. \& Clapcott, R. (2011). Developing public policy for climate change in the tourism sector. Journal of Policy Research in Tourism, Leisure and Events, 3 (1), 1-17.

Becken, S. \& Bobes, L. (2016). Proving the Case: Carbon Reporting in Travel and Tourism. Amadeus: Madrid.

Becken, S. \& Dolnicar, S. (2016). Uptake of resource efficiency measures among small and mediumsized accommodation and food service providers. Journal of Hospitality and Tourism Management, 26, 45-49.

Becken, S. \& MacKey, B. (2017). What role for offsetting aviation greenhouse gas emissions in a deep-cut carbon world? Journal of Air Transport Management, 63, 71-83.

Becken, S. \& Shuker, J. (2018). A framework to help destinations manage carbon risk from aviation emissions. Tourism Management. Online https://doi.org/10.1016/j.tourman.2018.10.023

Becken, S. \& Carmignani, F. (2019). Alternative scenarios for (declining) demand for air travel. Submitted to Tourism Management.

Bendell, J. (2018). Deep Adaptation: A Map for Navigating Climate Tragedy. IFLAS Occasional Paper 2. Available (20/12/18) www.iflas.info

Bennett, H. (2017). Have psychologists found a better way to persuade people to save the planet? The Guardian, 2 November. Available (20/10/18) https://www.theguardian.com/inequality/2017/nov/02/psychologists-better-way-persuadepeople-to-save-planet-environment

Bohdanowicz, P., Zientara, P. \& Novotna, E. (2011). International hotel chains and environmental protection: an analysis of Hilton's we care! programme (Europe, 2006-2008). Journal of Sustainable Tourism, 19(7), 797-816.

Bolderdijk, J.W. \& Steg, L. (2015). Promoting sustainable consumption: the risks of using financial incentives. Chapter 21. In: Reisch, L.A. \& Thøgersen, J. (eds). Handbook of Research on Sustainable Consumption. Cheltenham: Edward Elgar Publishing.

Buckley, R. (2011). Tourism under Climate Change: Will slow travel supersede short breaks? $A M B I O, 40,328-331$.

Buijtendijk, H., Blom, J., Vermeer, J. \& van der Duim, R. (2018). Eco-innovation for sustainable tourism transitions as a process of collaborative co-production: the case of a carbon management calculator for the Dutch travel industry. Journal of Sustainable Tourism, 26(7), $1222-1240$ 
Cames, M., Harthan, R., Füssler, J., Lazarus, M., Lee, C.M., Erickson, P. \& Spalding-Fecher, R. (2016). How additional is the Clean Development Mechanism? Analysis of the application of current tools and proposed alternatives. Study prepared for DG CLIMA. Available (01/03/19) https://ec.europa.eu/clima/sites/clima/files/ets/docs/clean_dev_mechanism_en.pdf

Dywer, L. (2018). Saluting while the ship sinks: the necessity for tourism paradigm change, Journal of Sustainable Tourism, 26(1), 29-48.

Global Sustainable Tourism Dashboard (2018). Data. Available (01/12/18) www.tourismdashboard.org

Gordon, E. (2000). Integrative neuroscience: Bringing together biological, psychological and clinical models of the human brain. Singapore: Harwood Academic Publishers.

Gössling, S., Hall, C.M., Peeters, P. \& Scott, D. (2010). The Future of Tourism: Can Tourism Growth and Climate Policy be Reconciled? A Mitigation Perspective. Tourism Recreation Research, 35(2), 119-130.

Gössling, S. \& Hall, C.M. (2019). Sharing versus collaborative economy: how to align ICT developments and the SDGs in tourism? Journal of Sustainable Tourism, 27 (1), 74-96.

Greenhouse (2018). Secrets of the disruptors. Disrupt markets. Tackle climate change. Available $(11 / 12 / 18)$ www.greenhousepr.co.uk

Hall, C.M. (2010). Changing Paradigms and Global Change: From Sustainable to Steady-state Tourism. Tourism Recreation Research, 35(2), 131-143.

Hall, C.M. (2013). Framing behavioural approaches to understanding and governing sustainable tourism consumption: beyond neoliberalism, "nudging" and "green growth"? Journal of Sustainable Tourism, 21(7), 1091-1109.

Hawken, P. (2010). The Ecology of Commerce. New York: Harper Collins Publisher.

Higham, J.E.S., Cohen, S.A. \& Cavaliere, C.T. (2014). Climate change, discretionary air travel and the 'flyers' dilemma'. Journal of Travel Research, 53(4), 462-475.

ICAO (2016). On board a sustainable future. Environmental Report 2016. Available (20/11/18) https://www.icao.int/environmentalprotection/Documents/ICAO\%20Environmental\%20Report\%202016.pdf

IPCC (2018). Global Warming of $1.5^{\circ} \mathrm{C}$. Summary for Policymakers. Available (14/11/18) http://report.ipcc.ch/sr15/pdf/sr15_spm_final.pdf

ITP (2017). Hotel Global Decarbonisation Report. London. Available (20/10/18) https://www.tourismpartnership.org/blog/itp-carbon-report-provides-hotel-sectors-goalmitigate-climate-change/

Jackson, T. (2018). Beyond redistribution on Limits to Growth. An economy that works. Confronting inequality in an era of low growth. Briefing Paper 2. Available (01/12/2018) www.limits2growth.org.uk/publications

Kashtan, M. (2015). Abundance, Inequality, Needs, and Privilege. Ideas about what we "deserve" are hindering gifting and collaboration. March 05. Psychology Today. Available (10/12/18) https://www.psychologytoday.com/au/blog/acquired-spontaneity/201503/abundanceinequality-needs-and-privilege

Keller, P.C. (1987). Stages of peripheral tourism development - Canada's northwest territories, Tourism Management, 8(1), 20-32.

Kilbourne, W.E., Beckmann, S.X. \& Thelen, E. (2002). The role of the dominant social paradigm in environmental attitudes. A multinational examination. Journal of Business Research, 55, 193204. 
Lane, B. (2017). Sustainable tourism: its evolution and its future. Cuadernos Económicos de ICE, 93, 9-28.

Lee, D. (2018). International aviation and the Paris Agreement temperature goals. Available $(01 / 01 / 19)$ https://assets.publishing.service.gov.uk/government/uploads/system/uploads/attachment_data/ file/763261/international-aviation-paris-agreement.pdf

Lenzen, M., Sun, Y., Faturay, F., Ting, Y., Geschke, A. \& Malik, A. (2018). The carbon footprint of global tourism. Nature Climate Change. https://doi.org/10.1038/s41558-018-0141-x

LocalYokl (2019). Homepage. Available (01/12/2018) https://localyokl.com/

Lyle, C. (2018). Building on ICAO's CORSIA to Achieve Environmental Sustainability for Aviation. Climate Law, 8(1-2), 104-127.

Lyon, T. (2018). Corporations' green promises are often undermined by their lobbying. World Changing Ideas. Fast Company, 20 June. Available (03/01/19) https://www.fastcompany.com/90204527/corporations-green-promises-are-often-underminedby-their-lobbying

Mann, G. \& Wainwright, J. (2018). Climate Leviathan. A political theory of our planetary future. London: Verso.

Milfont, T.L., Bain, P.G., Kashima, Y., Verdugo, V., Pasquali, C., Johansson, L., Guan, Y., Gouveia, V.V., Garðarsdóttir, R.B., Doron, G., Bilewicz, M., Utsugi, A., Aragones, J.I., Steg, L., Soland, M., Park, J., Otto, S., Demarque, C., Wagner, C., Madsen, O.J., Lebedeva, N., González, R., Schultz, P., Saiz, J.L., Kurz, T., Gifford, R., Akotia, C.S., Saviolidis, N.M. \& Einarsdóttir, G. (2017). On the relation between Social Dominance Orientation and environmentalism. A 25-Nation Study. Social Psychological and Personality Science, 9(7), 802-814.

Monbiot, G. (2018). Advertising and academia are controlling our thoughts. Didn't you know? The Guardian, 31 December. Available (03/01/19) https://www.theguardian.com/commentisfree/2018/dec/31/advertising-academia-controllingthoughts-universities

OECD (2017). How's life? 2017: Measuring well-being. Paris: OECD Publishing.

Offsetters (no date). Amia. Available (05/01/19). https://www.offsetters.ca/advisory-services/casestudies/AimiaCarbonNeutral

Parker, C., Letelier, M. \& Munoz, J. (2013). Elites, climate change and agency in a developing society: the Chilean case. Environment, Development \& Sustainability, 15, 1337-1363.

Peeters, P. M. \& Landré, M. (2012). The emerging global tourism geography - an environmental sustainability perspective. Sustainability, 4(1), 42-71.

Peeters, P., Higham, J., Cohen, S., Eijgelaar, E. \& Gössling, S. (2018). Desirable tourism transport futures. Journal of Sustainable Tourism. https://doi.org/10.1080/09669582.2018.1477785

Pollock, A. (2015). Social entrepreneurship in tourism: The conscious travel approach. Tourism, Innovation Partnership for Social Entrepreneurship. London, UK: TIPSE Tourism.

Pyke, S., Hartwell, H., Blake, A. \& Hemingway, A. (2016). Exploring well-being as a tourism product resource. Tourism Management, 55, 94-105.

Scott, D. \& Gössling, S. (2015). What could the next 40 years hold for global tourism?, Tourism Recreation Research, 40(3), 269-285.

Scott, D, Hall, C.M. \& Gössling, S. (2016). A report on the Paris Climate Change Agreement and its implications for tourism: why we will always have Paris. Journal of Sustainable Tourism, 24(7), 933-948. 
Shove, E., Pantzar, M. \& Watson, M. (2012). The dynamics of social practice: Everyday life and how it changes. London: Sage.

Sidanius, J. \& Felicia, P. (1999). Social Dominance: An Intergroup Theory of Social Hierarchy and Oppression. Cambridge: Cambridge University Press.

Simmons, D. G. (2017) Neoliberal politics and the fate of tourism. Pp. 9-24. In R. Butler \& W. Suntikul (Eds.). Tourism and political change, 2nd edition. Oxford: Goodfellow Publishers.

Statista (2018). Global advertising spending from 2014 to 2021. Available (12/12/18) https://www.statista.com/statistics/273288/advertising-spending-worldwide/

Steg, L., Perlaviciute, G. \& van der Werff, E. (2015). Understanding the human dimensions of a sustainable energy transition. Frontiers in Psychology, 6, 805.

The Club of Rome (2018). The Club of Rome Climate Emergency Plan. A Collaborative Call for Climate Action. Available (05/01/19) https://www.clubofrome.org/wpcontent/uploads/2018/12/COR_Climate-Emergency-Plan-final-pages.pdf

United Nations Climate Change (2018). UN Climate Change and WTTC Highlight Role of Travel and Tourism in Attaining a Carbon Neutral World by 2050. Press release 11 December, 2018. Available (05/01/19) https://unfccc.int/news/un-climate-change-and-wttc-highlight-role-oftravel-and-tourism-in-attaining-a-carbon-neutral-world

UNEP Finance Initiative (2018). At COP24: Group of 415 investors call on world leaders to address climate change. Available (01/12/18) http://www.unepfi.org/news/industries/investment/thelargest-ever-investor-statement-to-governments/

UNFCCC (2017). The Paris Agreement - main page. Available (09/11/18) http://unfccc.int/paris_agreement/items/9485.php

UNWTO (2017). Measuring Sustainable Tourism. Madrid. Available (09/11/18) http://cf.cdn.unwto.org/sites/all/files/docpdf/folderfactsheetweb.pdf

UNWTO \& Griffith University (2017). Managing Growth and Sustainable Tourism Governance in Asia and the Pacific. UNWTO: Madrid.

UNWTO \& UNEP (2017). Tourism and the Sustainable Development Goals - Journey to 2030. UNWTO: Madrid.

UNWTO (2018a). World Tourism Barometer, Volume 12(3). Madrid.

UNWTO (2018b). 2018 Poised to Advance Tourism's Leadership among Top Global Economic Sectors. Press release, 29 November. Madrid. Available (01/12/18)

http://www2.unwto.org/press-release/2018-11-28/2018-poised-advance-tourisms-leadershipamong-top-global-economic-sectors

UNWTO (2019). Who we are. Available (01/01/19) http://www2.unwto.org/content/who-we-are-0

Vos, J. (2009). Actions Speak Louder than Words: Greenwashing in Corporate America. Notre Dame Journal of Law Ethics \& Public Policy, 23(2), 673-697. Available (03/01/19) http://scholarship.law.nd.edu/ndjlepp/vol23/iss2/13

Wang, Z., Han, B. \& Lu, M. (2016). Measurement of energy rebound effect in households: Evidence from residential electricity consumption in Beijing, China. Renewable and Sustainable Energy Reviews, 58, 852-861.

Warren, C. \& Becken, S. (2017). Saving energy and water in tourist accommodation: a systematic literature review. International Journal of Tourism Research, 19(3), 289-303.

Warren, C., Becken, S. \& Coghlan, A. (2016). Using persuasive communication to co-create behavioural change - engaging with guests to save resources at tourist accommodation facilities. Journal of Sustainable Tourism, 25(7), 935-954. 
Warren, C., Becken, S., Nguyen, K. \& Stewart, R. (2018). Impact of a sustainability smart service on daily resource use in self-contained B\&B style tourist accommodation. Journal of Cleaner Production. Online https://doi.org/10.1016/j.jclepro.2018.08.063

WTTC (2018a). WTTC and UN Climate Change in new partnership to tackle climate change. Availabe (01/12/18) https://www.wttc.org/about/media-centre/press-releases/pressreleases/2018/wttc-and-un-climate-change-in-new-partnership-to-tackle-climate-change/

WTTC (2018b). Agenda. Available (01/11/18) https://www.wttc.org/agenda/

WTTC \& McKinsey \& Company (2017). Coping with success: Managing overcrowding in tourism destinations. London: World Travel and Tourism Council.

WTTC (2019). Importance \& Economic Impact of Domestic Tourism. London. Available (06/01/19) https://www.wttc.org/economic-impact/country-analysis/domestic-tourism/ 